\title{
Upaya Meningkatkan Kemampuan Berpikir Historis Melalui Penerapan Model Pembelajaran Resource Based Learning Di SMA Trenggalek
}

\author{
Danan Tricahyono ${ }^{1}$, Aditya Nugroho Widiadi ${ }^{2}$ \\ ${ }^{1}$ Magister Pendidikan Sejarah, Pascasarjana, Universitas Sebelas Maret \\ ${ }^{2}$ Jurusan Sejarah, Fakultas Ilmu Sosial, Universitas Negeri Malang \\ Email: danancahyono2@gmail.com
}

\begin{abstract}
Abstrak: Guna menghasilkan pembelajaran sejarah yang bermakna maka setiap siswa harus dibekali dengan kemampuan berpikir untuk memahami sejarah. Salah satu kemampuan berpikir yang harus dimiliki siswa kaitannya dengan pembelajaran sejarah adalah berpikir historis. Tujuan penelitian ini untuk meningkatkan kemampuan berpikir historis melalui penerapan model pembelajaran Resource Based Learning (RBL). Penelitian ini menggunakan pendekatan penelitian tindakan dan jenis penelitian PTK. Subjek penelitian adalah siswa kelas XI IPA 1 SMA Negeri 1 Durenan dengan jumlah 11 siswa laki-laki dan 24 siswa perempuan. Teknik pengumpulan data menggunakan wawancara, observasi dan tes. Analisis data menggunakan naratif kualitatif. Hasil penelitian menunjukan bahwa penerapan Resource Based Learning (RBL) dapat meningkatkan kemampuan berpikir historis. Dari hasil tes kemampuan berpikir historis pada siklus 1 perolehan rata-rata skor sebesar 52.82. Sementara pada siklus 2 mengalami kenaikan menjadi 72.88. Dari hasil analisis dapat diketahui jika siswa mampu menguasai lima aspek kemampuan berpikir historis yang meliputi: (1) berpikir kronologis, (2) pemahaman sejarah, (3) analisis dan interpretasi kesejarahan, (4) kemampuan penelitian kesejarahan, (5) analisis isu kesejarahan dan pengambilan keputusan.
\end{abstract}

\section{Kata kunci: Resource Based Learning, Historis, Pembelajaran}

Abstract: To produce meaningful historical learning, each student must be equipped with the ability to think to understand history. One of the thinking skills that students must have to do with learning history is historical thinking. The purpose of this study is to improve the ability to think historically through the application of the Learning Model for Resource-Based Learning (RBL). This study uses an action research approach and the type of CAR research. The research subjects were students of class XI Science 1 of SMA Negeri 1 Durenan with a total of 11 male students and 24 female students. Data collection techniques using interviews, observation, and tests. Data analysis using qualitative narrative. The results showed that the application of Resource-Based Learning (RBL) could improve the ability to think historically. From the results of the test of historical thinking ability in cycle 1, the average score was 52.82. While in cycle 2 it increased to 72.88. From the results of the analysis it can be seen if students are able to master five aspects of historical thinking abilities which include: (1) chronological thinking, (2) historical understanding, (3) historical analysis and interpretation, (4) historical research ability, (5) historical analysis and decision making.

\section{Keywords: Resource Based Learning, Historis, Teaching}

\section{Pendahuluan}

Pembelajaran sejarah merupakan serangkaian kegiatan siswa dan guru dengan menggunakan fasilitas pembelajaran serta materi sejarah yang di dalamnya mengandung nilai-nilai kearifan yang dapat digunakan untuk melatih kecerdasan, sikap, dan kepribadian siswa
(Jati, 2015). Jadi, pembelajaran sejarah mengarahkan siswa ke arah yang lebih baik dengan mengambil nilai-nilai positif dari peristiwa di masa lalu agar dijadikan pedoman untuk kehidupan sehari-hari. Sejarah memiliki arti strategis dalam penanaman dan pengembangan kesadaran sejarah dalam diri siswa (Wijanarti, 2012). 
Penguatan kesadaran siswa dalam belajar sejarah merupakan hal yang penting sebagai upaya membangkitkan minat siswa dalam belajar di kelas (Hamid, 2014).

Dalam pembelajaran sejarah saat ini didesain untuk menjadikan siswa mampu berpikir historis. Secara sederhana kemampuan berpikir historis adalah pemahaman yang tepat akan konsep waktu, ruang, dan masyarakat (Kochar, 2008). Maka kemampuan berpikir historis harus dimiliki oleh siswa. The Braedly Commisions on History School and the National Standart for History dalam (Murni, 2013) mengungkapkan secara rinci kemampuan berpikir historis adalah:

"Historical thinking involves the explorations and analysis of historical document, places, artifact, and other record of the past .... this requeres the children thoughtfully listen to and read well written historical narrative that reveal conditions, changes, and consequences, and that explain why happened as they did. Analysis of the events disribe and the explanations offered, in tandem and comparasion with historical artifac, record, and the human figures involved, bring's a child ability to think historical thinking fill circle."

Dari pendapat tersebut dapat

diketahui jika peranan dokumen atau catatan sejarah, lokasi dari peristiwa sejarah, benda-benda sejarah dan rekaman tentang masa lalu memiliki peranan sangat besar dalam mengarahkan siswa untuk menganalisis peristiwa sejarah guna mengembangkan kemampuan berpikir historisnya. Jadi, pelajaran sejarah tidak hanya menuntut siswa menghafal materi pelajaran saja tetapi juga mengembangkan kemampuan berpikirnya, dalam hal ini berpikir historis. Dalam praktiknya belum semua guru mampu menghadirkan pembelajaran sejarah yang membawa siswa mampu mengembangkan kemampuan berpikir historis.

Hal ini juga terjadi di kelas XI IPA 1 SMA Negeri 1 Durenan Trenggalek. Kelas tersebut dipilih sebagai subjek penelitian dengan alasan sebab kelas unggulan dengan prestasi belajar siswa tinggi tetapi, kemampuan berpikir historisnya rendah. Dapat dilihat saat pembelajaran sejarah berlangsung terdapat beberapa indikator mengenai rendahnya kemampuan berpikir historis diantaranya Pertama, ketidakmampuan siswa menggambarkan peristiwa sejarah dalam bentuk peta sejarah, bagan, grafik, dan tabel.

Poin-poin tersebut merupakan salah satu aspek kemampuan berpikir historis pada aspek pemahaman sejarah. Kedua, siswa belum memiliki kemampuan menyusun periodisasi sejarah dengan benar. Hal ini menunjukkan rendahnya kemampuan menyusun garis waktu secara kronologis (Murni, 2013). Ketiga, ketidakmampuan siswa menganalisis isu dan pengambilan keputusan dalam pembelajaran sejarah (Murni, 2013). Keempat, rendahnya kemampuan melakukan analisis dan interpretasi 
terhadap peristiwa sejarah (Murni, 2013). Rendahnya kemampuan berpikir historis disebabkan oleh dua faktor utama yaitu pembelajaran yang bersifat teacher oriented dan minimnya penggunaan sumber belajar.

Kondisi pembelajaran didominasi dengan ceramah dan modul digunakan sebagai satu-satunya sumber pembelajaran. model pembelajaran yang sering dilakukan diawali ceramah kemudian guru memberikan tugas kepada siswa untuk mengerjakan soal-soal pada modul. Dampaknya kemampuan berpikir siswa menjadi tidak berkembang karena siswa hanya meniru informasi yang diberikan oleh guru. Idealnya guru mampu menerapkan pembelajaran yang mengarahkan sekaligus mengembangkan kemampuan berpikir historis siswa.

Pembelajaran yang mengarahkan pada pengembangan kemampuan berpikir dapat dilakukan dengan cara menerapkan model pembelajaran yang bersifat student oriented (Aziz, Zahara \& Ismail, 2007). Pembelajaran student oriented mengajak siswa mampu melakukan penghayatan dan memproses informasi sehingga diperoleh pengetahuan yang baru (Santyasa, 2007). Pembelajaran dengan student oriented akan lebih bermakna bagi siswa karena siswa terlibat aktif sebagai subjek pembelajaran. Kesenjangan tersebut perlu diberi pemecahan solusi. Sebagai solusinya peneliti memberikan alternatif model pembelajaran yang membawa siswa mengembangkan kemampuan berpikir tentang cara mengolah informasi dari sejumlah sumber belajar belajar.

Kajian penelitian tentang upaya peningkatan kemampuan berpikir historis masih sedikit dilakukan. Salah satu penelitian yang pernah dilakukan oleh (Khaifiyah, 2014) dengan menggunakan novel sejarah sebagai sumber belajar untuk meningkatkan kemampuan berpikir historis. Maka peneliti memiliki inisiatif memberikan solusi model pembelajaran Resource Based Learning dengan memanfaatkan buku-buku sejarah koleksi perpustakaan sekolah.

Resource Based Learning merupakan segala bentuk belajar yang langsung menghadapkan siswa dengan suatu atau sejumlah sumber belajar baik secara individu maupun kelompok dengan segala kegiatan pembelajaran yang bertalian dengan sumber belajar (Sagala, 2009). Peranan guru menjadi tidak dominan. Dalam pembelajaran tersebut tujuan utamanya mengembangkan daya kreatifitas siswa, terutama dalam hal menemukan sumber belajar. Dalam Resource Based Learning guru tidak menjadi satu-satunya sumber belajar. Siswa dapat belajar dalam kelas, dalam ruang perpustakaan, bahkan di luar sekolah jika mempelajari lingkungan yang berhubungan dengan tugas tertentu. Pada hakikatnya model pembelajaran Resource Based Learning bersifat fleksibel 
bergantung pada putusan guru serta kemungkinan yang ada dalam kurikulum di sekolah. Jadi Resource Based Learning bisa dipakai dalam berbagai segi, misalnya pembelajaran berprogram atau yang mengikuti prosedur yang telah ditentukan maupun pembelajaran bebas yang berdasarkan pemecahan masalah, penelitian, dan penemuan.

Model Resource Based Learning merupakan pembelajaran yang pada intinya diarahkan kepada siswa (Ryan, Wells, Freeman, \& Hallam, 1996). Guru hanya berperan pada setiap langkah proses belajar, mulai dari perencanaan, penentuan atau pengumpulan sumber informasi, memberikan motivasi, bantuan dan memperbaiki kesalahan. Dengan demikian proses pembelajaran menjadi lebih bermakna bagi siswa.

Dengan modal pengetahuan yang mereka miliki siswa dapat memecahkan masalah dalam pembelajaran sejarah dengan menggunakan sejumlah sumber belajar (Sagala, 2009). Berdasarkan uraian sebelumnya artikel ini akan mengajak pembaca untuk mengetahui upaya meningkatkan kemampuan berpikir historis melalui penerapan model pembelajaran Resource Based Learning.

\section{Metode}

Penelitian ini menggunakan pendekatan penelitian tindakan dengan jenis Penelitian Tindakan Kelas (PTK)
(Sumadayo, 2013). PTK merupakan bentuk penelitian reflektif yang dilakukan oleh guru sendiri yang hasilnya dapat dimanfaatkan sebagai alat untuk pengembangan kurikulum, pengembangan sekolah, pengembangan keahlian mengajar (Suroso, 2007). PTK dilaksanakan melalui tahap-tahap perencanaan, pelaksanaan \& pengamatan, serta refleksi. Peneliti menggunakan model PTK yang dikembangkan oleh Kemmis \& Mc Taggart (Dasna, 2008).

Model tersebut memiliki tahapan perencanaan, tindakan (act) \& pengamatan (observation), dan refleksi (reflection). Pelaksanaan tindakan direncanakan dalam dua siklus. Siklus 1 terdiri dari dua pertemuan. Pertemuan pertama digunakan untuk menerapan model Resource Based Learning (RBL). Sementara pada pertemuan kedua digunakan untuk pelaksanaan tes kemampuan berpikir historis.

Pola yang sama juga terjadi pada siklus 2. Pertemuan pertama digunakan untuk penerapan model Resource Based Learning (RBL). Pertemuan kedua digunakan untuk pelaksanaan tes guna mengetahui tingkat kemampuan berpikir historis. Pada pelaksanaan PTK peneliti berperan sebagai guru pemberi tindakan (Wiriaatmadja, 2014). Guna mencatat segala aktivitas pembelajaran peneliti dibantu oleh dua orang observer. Yang bertindak sebagai observer adalah guru 
kelas dan satu teman sejawat. Peneliti juga dibantu satu teman yang berperan mendokumentasikan pelaksanan tindakan lewat rekaman video. Penelitian dilaksanakan di SMA Negeri 1 Durenan Trenggalek. SMA Negeri 1 Durenan berlokasi di Jalan Raya Kendalrejo Nomor 82 Kecamatan Durenan Kabupaten Trenggalek. Subjek penelitiannya di kelas XI IPA 1 dengan jumlah 11 siswa laki-laki dan 24 siswa perempuan.

Teknik pengumpulan data menggunakan observasi, wawancara dan tes. Untuk mengetahui tingkat kemampuan berpikir historis siswa, peneliti menggunakan instrumen berupa soal-soal dengan mengacu pada indikator berpikir historis. Analisis data menggunakan teknik analisis data kualitatif, sehingga penelitian tindakan teknik analisis datanya bersifat naratif-kualitatif. Data dianalisis dan diinterpretasikan baru dilanjutkan dengan evaluasi (Sukmadinata, 2015).

Tahap evaluasi bertujuan untuk mengetahui keefektifan tindakan dan kesesuain dampak tindakan yang diharapkan oleh peneliti. Hasil dari evaluasi akan dijadikan pedoman dalam melakukan refleksi ketercapaian tindakan. Tahap terakhir berupa refleksi. Kegiatan tersebut dilakukan peneliti bersama guru dengan tujuan mengkaji dan menganalisis PTK pada setiap siklus dengan jalan mengidentifikasi hal-hal yang terjadi selama pemberian tindakan termasuk kemajuan dan hambatan yang terjadi. Peneliti mencoba merenungkan tindakan perbaikan yang dapat digunakan untuk meningkatkan keefektifan tindakan, harapanya bisa lebih baik untuk tindakan berikutnya dan tujuan PTK dapat tercapai.

\section{Hasil Dan Pembahasan}

\section{Siklus 1}

Pelaksanaan tindakan siklus 1 meliputi tahapan perencanaan, tindakan \& observasi, serta refleksi. Pada tahap perencanaan peneliti berkolaborasi dengan guru menyusun Rencana Pelaksanaan Pembelajaran (RPP). Materi pelajaran siklus 1 membahas seputar kedatangan Sekutu dan NICA (Nederlansche Indies Civel Administrations) serta perlawanan rakyat di berbagai daerah. Peneliti menyiapkan sejumlah sumber belajar yang diambil dari koleksi perpustakaan sekolah. Pelaksanaan tindakan siklus 1 terdiri dari dua pertemuan.

Pertemuan pertama dilaksanakan dengan alokasi waktu 45 menit. Pertemuan pertama digunakan untuk menerapkan model pembelajaran RBL. Pertemuan kedua dilaksanakan dengan alokasi waktu 45 menit. Pertemuan kedua digunakan untuk pelaksanakan tes guna mengetahui tingkat kemampuan berpikir historis para siswa. Langkah-langkah penerapan Resource Based Learning (RBL) diawali dengan apersepsi oleh guru sebagai pemberi tindakan dengan menunjukan 
tokoh Bung Tomo. Kegiatan inti siswa mulai mengembangkan pertanyaan seputar keterlibatan orang-orang Trenggalek dalam perjuangan mempertahankan kemerdekaan Indonesia. Selain itu, muncul pertanyaan seputar peristiwa paling fenomenal dari pertempuran-pertempuran di berbagai daerah.

Guna menemukan jawaban tersebut peneliti sebagai guru pemberi tindakan memberikan sedikit pengantar informasi salah satu peristiwa fenomenalnya adalah Pertempuran 10 November 1945 kepada siswa sebagai bekal mencari informasi. Para siswa mencari informasi dari buku teks milik perpustakaan sekolah. Buku yang digunakan meliputi: 1) Sejarah Nasional Indonesia Jilid 3, 2) Sejarah Nasional dan Umum dan 3) Pendidikan Sejarah Perjuangan Bangsa. Dari hasil menemukan informasi dari sejumlah sumber siswa memilih informasi yang relevan dengan kebutuhan. Siswa membandingkan informasi dari satu sumber dengan sumber lainnya.

Dari perbandingan tersebut siswa dapat menentukan informasi yang dibutuhkan. Pada tahap akhir siswa diberi kesempatan untuk menyampaikan informasi di depan kelas. Hasil observasi pada siklus 1 menunjukan langkah-langkah penerapan Resource Based Learning kurang dipahami siswa. Pada langkah menyampaikan informasi yang terjadi justru siswa bertanya kepada peneliti.
Pelaksanaan pembelajaran juga molor 5 menit. Hasil pengukuran kemampuan berpikir historis pada pertemuan kedua menunjukan angka yang masih rendah. Berdasarkan hasil tes dapat dilihat jika rata-rata skor perolehan siswa menunjukan angka 52.82. Dengan mengacu pada Kriteria Ketuntasan Minimal (KKM) yaitu 75 maka dapat dilihat di lampiran menunjukan siswa yang mendapat $\geq 75$ sebanyak 9 siswa dan $\leq 75$ sebanyak 26 siswa.

Refleksi pada siklus 1 membahas mengenai jalannya pembelajaran. Para observer dan peneliti mendiskusikan permasalahan yang terjadi selama pembelajaran. Permasalahan yang perlu mendapat perhatian terkait pengelolaan kelas, penerapan Resource Based Learning dan hasil tes kemampuan berpikir historis. Penerapan model Resource Based Learning yang belum maksimal serta beberapa indikator dalam berpikir historis yang belum tercapai menunjukan jika pelaksanaan pembelajaran pada siklus 1 belum memenuhi harapan.

Dengan demikian peneliti memutuskan untuk terus melakukan perbaikan pada siklus 2. Guna menutupi kekurangan pada siklus 1 peneliti dan guru mencari solusi pemecahan. Peneliti bersama guru sepakat jika pada saat pembelajaran, siswa diberi penjelasan seputar Resource Based Learning. Untuk indikator-indikator kemampuan berpikir 
historis juga lebih ditekankan pada siswa. Peneliti berencana menggunakan garis waktu untuk pembelajaran di siklus 2 guna mengarahkan siswa menguasai aspek chronological thinking (berpikir kronologis). Harapannya siswa mampu memahami materi pembelajaran dengan mudah dan mampu meningkatkan kemampuan berpikir historisnya.

Siklus 2

Pelaksanaan tindakan siklus 2 merupakan bentuk perbaikan dari siklus 1 . Tahapan siklus 2 meliputi perencanaan, tindakan \& observasi, dan refleksi. Pada tahap perencanaan peneliti berkolaborasi dengan guru untuk menyusun Rencana Pelaksanaan Pembelajaran (RPP) dengan sedikit melakukan modifikasi pembelajaran dengan metode diskusi kelompok. Materi pelajaran pada siklus 2 seputar perjuangan diplomasi untuk mempertahankan kemerdekaan Indonesia.

Pelaksanaan tindakan siklus 2 terbagi menjadi dua pertemuan. Pertemuan pertama diberi alokasi waktu 45 menit dan pertemuan kedua dilaksanakan alokasi waktu 45 menit. Pertemuan pertama digunakan untuk penerapan model RBL sementara pertemuan kedua kegiatannya berupa tes untuk mengetahui tingkat kemampuan berpikir historis siswa. Penerapan Resource Based Learning (RBL) diawali dengan apersepsi dengan mengulas tokoh Sutan Syahrir dan lokasi Perundingan Linggarjati. Kegiatan inti siswa mulai mengembangkan pertanyaan seputar materi perjuangan diplomasi. Salah satu siswa bernama MI mengungkapkan pertanyaan seputar alasan dipilihnya Sutan Syahrir sebagai delegasi Indonesia pada Perundingan Linggarjati. Guna menemukan jawaban tersebut peneliti sebagai guru pemberi tindakan memberikan sedikit pengantar informasi seputar kedudukan Sutan Syahrir dalam struktur pemerintahan Republik Indonesia.

Peneliti sebagai guru pemberi tindakan mengarahkan siswa untuk menemukan informasi seputar alasan pemilihan Sutan Syahrir serta informasiinformasi seputar perjuangan diplomasi mulai dari Perundingan Linggarjati, Renville, Roem-Royen dan Hooge-Veluwe. Para siswa mencari informasi dari buku teks Sejarah Nasional Indonesia Jilid dan Sejarah Nasional dan Umum serta modul MGMP. Dari hasil menemukan informasi dari sejumlah sumber siswa memilih informasi yang relevan dengan kebutuhan.

Siswa membandingkan informasi dari satu sumber dengan sumber lainnya. Dari perbandingan tersebut siswa dapat menentukan informasi yang dibutuhkan. Pada tahap akhir siswa diberi kesempatan untuk menyampaikan informasi di depan kelas. Hasil observasi menunjukan pelaksanaan siklus 2 lebih baik apabila dibandingkan dengan siklus 1 . Para siswa ketika belajar sudah mengikuti instruksi yang diberikan oleh peneliti sebagai guru 
pemberi tindakan. Setiap siswa dapat bertanggung jawab terhadap masingmasing kelompoknya. Pada proses mencari informasi melalui sumber setiap siswa aktif membuka, membaca dan melakukan pencatatan beberapa informasi yang telah diperoleh. Pada saat penyampaian informasi di depan kelas, masing-masing kelompok bertanggung jawab untuk maju ke depan kelas tanpa adanya saling tunjuk diantara anggota kelompok.

Hasil pengukuran kemampuan berpikir historis yang diperoleh menunjukan peningkatan. Berdasarkan hasil tes dapat dilihat jika rata-rata skor perolehan siswa menunjukan angka 72.88 . Dengan mengacu pada Kriteria Ketuntasan Minimal (KKM) yang digunakan di SMA Negeri 1 Durenan yaitu 75 maka dapat dilihat di lampiran menunjukan siswa yang mendapat $\geq 75$ sebanyak 27 siswa dan $\leq 75$ sebanyak 8 siswa.

Kegiatan refleksi siklus 2 terlihat terjadi peningkatan kualitas pembelajaran di kelas XI IPA 1 yang mengarah ke arah yang lebih baik. Meningkatnya kualitas pembelajaran dijadikan acuan oleh peneliti dan observer dalam penerapan siklus berikutnya. Adanya peningkatan kualitas pembelajaran menjadi tolok ukur jika pemberian tindakan tidak perlu dilanjutkan pada siklus berikutnya dengan pertimbangan penerapan Resource Based Learning sudah yang sesuai yang diharapkan peneliti dan observer. Hasil pengukuran kemampuan berpikir historis pada siklus 2 mengalami kenaikan jika dibandingkan pada siklus 1. Hasil tes kemampuan berpikir historis pada siklus 2 sebesar 72.88 sementara siklus 1 sebesar 52.82.

Peningkatan kemapuan berpikir historis menunjukan jika siswa telah mampu menguasai lima aspek kemampuan berpikir historis yang meliputi: (1) chronological thinking (berpikir kronologis), (2) historical comprehension (pemahaman sejarah), (3) historical analysis and interpretations (analisis dan interpretasi kesejarahan), (4) historical research capabilities (kemampuan penelitian kesejarahan), (5) Historical issues analysis and decision making (analisis isu kesejarahan dan pengambilan keputusan).

Indikator dalam berpikir historis yang mampu dicapai oleh siswa dijadikan tolok ukur untuk pemberian tindakan lanjutan. Tercapainya lima indikator berpikir historis menjadikan peneliti bersama guru memutuskan untuk tidak memberikan tindakan lanjutan.

\section{Penerapan Model Resource Based} Learning dalam Pembelajaran Sejarah

Pembelajaran sejarah dengan menggunakan model Resource Based Learning (RBL) dilaksanakan selama dua siklus. Penerapan Resource Based Learning (RBL) pada siklus pertama berupa kegiatan pembelajaran. Materi pembelajaran pada 
siklus 1 seputar kedatangan Sekutu dan NICA serta perlawanan rakyat di berbagai daerah. Penerapan model Resource Based Learning (RBL) pada siklus 1 berjalan belum maksimal. Hal ini ditandai dengan penerapan Resource Based Learning (RBL) yang masih belum dipahami oleh sebagian siswa. Pada langkah menyampaikan informasi terjadi kebingungan dari siswa yang bernama $\mathrm{KB}$, ia yang justru bertanya seputar kepergian Sekutu dari Indonesia kepada peneliti sebagai guru pemberi tindakan.

$$
\text { Kendala lainnya suasana }
$$
pembelajaran belum kondusif. Sebagian besar siswa masih sering berdiskusi dengan teman satu bangkunya membicarakan topik diluar pelajaran. Selain sisi negatif juga terdapat sisi positif. Pada siklus 1 sisi positif yang terlihat berupa suasana pembelajaran telah berorientasi ke siswa (student oriented), dimana siswa aktif mencari informasi dari sejumlah buku sumber.

Melihat kekurangan yang ada pada siklus 1 peneliti bersama observer mencari solusi guna meningkatkan suasana pembelajaran ke arah yang lebih baik pada siklus 2. Idealnya pembelajaran yang baik itu mampu mengembangkan sikap positif siswa terhadap kegiatan pembelajaran (Santyasa, 2007). Sikap positif siswa terhadap pembelajaran dapat dirasakan dan terlihat pada siklus 2. Suasana pembelajaran pada siklus 2 lebih kondusif.
Penerapan model Resource Based Learning (RBL) dipahami dengan baik oleh siswa. Langkah-langkah Resource Based Learning (RBL) yang terdiri dari tahap mengidentifikasi pertanyaan atau masalah yang terkait dengan pembelajaran, mencari informasi, menggunakan informasi, mensintesis informasi, dan evaluasi dilaksanakan dengan baik sesuai sintak yang tercantum dalam RPP. Terlebih pada kegiatan mencari informasi satu siswa dengan lainya saling bertanggung jawab dalam rangka menemukan informasi yang dibutuhkan.

Hal ini tidak lepas dari inovasi pembelajaran yang dilakukan oleh peneliti dengan metode diskusi kelompok. Pembelajaran yang mengarahkan siswa menjadi lebih baik adalah suatu keharusan dan sangat penting (Varshney, 2014). Pada siklus 2 potensi yang dimiliki siswa sudah terlihat. Pada siklus 1 jumlah siswa yang berani berbicara di depan kelas masih dua orang sementara siklus 2 meningkat menjadi delapan orang.

Peningkatan Kemampuan Berpikir Historis Melalui Penerapan Model Pembelajaran Resource Based Learning

Penerapan model pembelajaran Resource Based Learning dengan memanfaatkan buku teks sebagai sumber belajar dapat menjadikan siswa mengembangkan kemampuan berpikir historisnya. Pada siklus 1 indikator kemampuan berpikir historis yang nampak 
yaitu aspek historical capabilities research (Murni, 2013). Siswa yang bernama KB pada langkah apersepsi sudah mampu merumuskan pertanyaan dari hasil pertemuannya dengan gambar tokoh Bung Tomo. Ia mampu merumuskan pertanyaan seputar keterlibatan orang Trenggalek dalam pertempuran mempertahkan kemerdekaan Indonesia.

Kemampuan berpikir historis aspek historical comprehension juga nampak. Dari hasil membaca sejumlah narasi dalam buku teks KB tidak menemukan secara jelas kepergian Sekutu dari Indonesia. Kemampuan siswa menemukan kejanggalan pada narasi sejarah menunjukkan jika keterampikan mengidentifikasi elemen-elemen narasi sejarahnya sudah nampak. Sehingga siswa mampu memunculkan pertanyaan seputar kepergian Sekutu dari Indonesia.

Kemampuan mengidentifikasi elemen-elemen dalam narasi sejarah merupakan salah satu aspek kemampuan berpikir historis aspek historical comprehension (Murni, 2013). Aspek chronological thinking pada indikator kemampuan menyusun garis waktu secara kronologis muncul pada siklus yang terlihat dari penjelasan MI yang mengulas seputar pertempuran Ambarawa. Ia menjelaskan kedatangan Sekutu sampai kepergian Sekutu dari Ambarawa (Murni, 2013). Sementara pada siklus 2 kemampuan berpikir historis siswa lebih banyak yang nampak. Dari hasil refleksi siklus 1, penerapan model pembelajaran Resource Based Learning pada siklus 2 menggunakan metode diskusi kelompok. Dengan metode diskusi harapannya semua siswa semakin terlibat dalam kegiatan pembelajaran. Indikator kemampuan berpikir historis nampak dari kelompok A yang diwakili oleh NKP. Ia mampu menjelasankan keputusan Sutan Syahrir dipilih menjadi delegasi Indonesia pada Perundingan Linggarjati.

Kemampuan menilai pengambilan suatu keputusan di masa lalu merupakan kemampuan berpikir historis pada aspek historical issues analysis and decision making. Pada aspek historical issues analysis and decision making disebutkan jika salah satu indikatornya siswa mampu mengevaluasi suatu pengambilan keputusan manusia di masa lalu (Murni, 2013). NKP juga mampu mampu memahami materi sejarah dengan baik.

Dibuktikan dengan perspektifnya menilai Perundingan Linggarjati sebagai upaya mendapatkan pengakuan internasional. Kemampuan tersebut masuk pada kemampuan berpikir historis pada aspek historical comprehension. Pada aspek historical comprehension disebutkan jika salah satu indikatornya siswa mampu menilai suatu makna di balik peristiwa (Murni, 2013). KB sebagai perwakilan dari kelompok B lebih bagus dalam penyampaian informasi seperti yang 
diharapkan oleh peneliti. KB menyampaikan informasi dengan mengacu pada kemampuan berpikir historis aspek historical research capabilities. Ia menggunakan pola $5 \mathrm{~W}+1 \mathrm{H}$ untuk menjelaskan informasi seputar Agresi Militer Belanda 1. Pada aspek historical research capabilities disebutkan beberapa indikatornya berupa siswa didorong untuk mampu merumuskan pertanyaanpertanyaan dari pertemuanya dengan sumber sejarah dan memiliki kemampuan membangun interpretasi sejarah (Murni, 2013).

Kemampuan berpikir historis pada aspek historical analysis and interpretation juga terlihat pada diri EFS dari kelompok E yang sangat baik dalam menjelaskan seputar peristiwa pemberontakan PKI Madiun 1948. Ia memiliki multi perspektif dalam memandang munculnya peristiwa pemberontakan PKI Madiun 1948. Ia memandang jika penyebab munculnya pemberontakan PKI Madiun 1948 tidak hanya disebabkan jatuhnya kabinet Amir Syarifuddin tetapi, kedatangan Muso dari Uni Soviet ikut menggerakkan semakin masifnya kemunculan PKI di Madiun 1948.

Kemampuan memiliki multi perspektif merupakan salah satu indikator dari berpikir historis aspek historical analysis and interpretation. Pada aspek tersebut harapannya siswa mampu memiliki multi perspektif dalam melihat pengalaman manusia dalam data sejarah
(Murni, 2013). MI sebagai delegasi dari kelompok $\mathrm{F}$ menjelaskan dengan baik seputar Agresi Militer Belanda 2. Ia mampu menunjukan kemampuannya dalam mengidentifikasi isu dalam sejarah seputar munculnya Agresi Militer Belanda 2. Ia menyebutkan jika terjadinya Agresi Militer Belanda 2 sebagai bentuk pengkhianatan Belanda terhadap Perundingan Renville. Kemampuan mengidentifikasi isu di masa lalu merupakan indikator dari kemampuan berpikir historis aspek historical analysis and decision making (Murni, 2013).

SV sebagai delegasi kelompok $\mathrm{H}$ menjelaskan secara kronologis Secara kronologis Konferensi Inter-Indonesia dilaksanakan sebanyak dua kali. Konferensi Inter-Indonesia 1 dilaksanakan tanggal 1922 Juli 1949 di Yogyakarta sementara Konferensi Inter Indonesia 2 dilaksanakan tanggal 30 Juli-2 Agustus 1949 di Jakarta. Kemampuan menyusun garis waktu secara kronologis merupakan indikator dari kemampuan berpikir historis aspek chronological thinking (Murni, 2013).

Jadi pembelajaran sejarah dengan model Resource Based Learning berdampak pada kegiatan mental siswa aktif untuk bepikir (Yanzi, 2011). Siswa menemukan sejumlah informasi dari pertemuannya dengan sejumlah sumber belajar. Dari pertemuannya dengan sejumlah sumber belajar siswa mampu menentukan informasi yang dibutuhkan dalam hubunganya dengan topik pembelajaran. 
Penerapan Resource Based Learning membuat siswa lebih terlibat aktif dalam kegiatan pembelajaran. Aktivitas pembelajaran yang dilakukan menjadi lebih bermakna. Penerapan model Resource Based Learning di kelas XI IPA 1 dapat meningkatkan kemampuan berpikir historis. Hasil pengukuran kemampuan berpikir historis dari siklus 1 ke siklus 2 mengalami kenaikan.

Adapun rata-rata nilai yang diperoleh pada siklus 1 sebesar 52.82 lalu naik menjadi 72.88 pada siklus 2. Pada siklus 1 dengan mengacu pada Kriteria Ketuntasan Minimal (KKM) yang digunakan di SMA Negeri 1 Durenan yaitu 75. Siswa yang mendapat nilai $\geq 75$ sebanyak 9 siswa dan $\leq 75$ sebanyak 26 siswa. Pada siklus 2 siswa yang mendapat $\geq 75$ sebanyak 27 siswa dan $\leq 75$ sebanyak 8 siswa. Skor yang diperoleh siswa pada tes kemampuan berpikir historis siklus 1 masih rendah.

Penyebab masih rendahnya kemampuan berpikir historis dapat dilihat dari beberapa siswa yang belum mampu menyelesaikan soal dengan aspek berpikir kronologis dalam menyusun garis waktu sejarah, siswa belum mampu melakukan analisis terhadap pengambilan suatu keputusan dalam peristiwa sejarah, pemahaman siswa terhadap sejarah juga masih rendah terlihat dari kemampuan memahami narasi sejarah secara imajinatis yang rendah. Terlihat juga kemampuan analisis dan interpretasi sejarah yang rendah yang dibuktikan dengan rendahnya kemampuan memiliki multi perspektif terhadap suatu peristiwa. Pada pelaksanaan tes berpikir historis siklus 2 sebagian besar siswa sudah mampu berpikir secara kronologis. Siswa bisa menyusun garis waktu tentang tanggal pelaksanaan perundingan Hooge-Veluwe sebagai tonggak awal perjuangan diplomasi yang ditempuh bangsa Indonesia.

Pemahaman sejarah siswa juga sudah baik, siswa mampu menjawab pertanyaan tentang peta buta lokasi perundingan Linggarjati. Kemampuan analisis dan interpretasi siswa juga mulai nampak. Para siswa bisa menganalisis munculnya Agresi Militer Belanda 1. Kemampuan analisis isu dan pengambilan keputusan siswa sudah nampak. Rata-rata siswa mampu menjawab soal seputar keputusan pendirian PDRI. Kecakapan siswa dalam penelitian sejarah sudah bagus.

Siswa sudah bisa memberikan argumen berdasarkan data-data sejarah mengenai periode setelah Perundingan Roem-Royen yang dikenal sebagai masa memulihkan persatuan nasional. Kemampuan siswa mencari fakta, keinginan mencari bukti sejarah untuk dijadikan dasar pada saat berargumen dan kemampuan menentukan hubungan sebabakibat akan memiliki pengaruh terhadap pemahaman sejarah siswa menjadi baik. Pemahaman sejarah yang baik akan 
menjadikan siswa sebagai seorang pemikir sejarah (Garvey, B; Krug, 2015). Hal ini tidak lepas dari cara pemikir sejarah yang memang berbeda dari cara berpikir seharihari. Dasar berpikir sejarah adalah mengubah struktur berpikir dengan lebih mampu memahami makna masa lalu, sejarah tidak hanya menghafal seputar nama-nama, tanggal-tanggalnya dan kejadian kejadian akan tetapi siswa memiliki kemampuan membaca, memahami hasil naratif sejarah secara imajinatis, mampu mengidentifikasi elemen-elemen struktur cerita sejarah (Wineburg, 2006).

\section{Kesimpulan}

Kesimpulan penelitian menunjukan pembelajaran dengan menerapkan model Resource Based Learning dapat memberikan kontribusi meningkatkan kualitas pembelajaran. Apabila sebelumnya pembelajaran yang dilaksanakan di kelas XI IPA 1 bersifat teacher oriented, dengan penerapan model Resource Based Learning pembelajaran menjadi lebih bersifat student centered sehingga potensi yang dimiliki siswa menjadi terlihat seperti pada saat diskusi kelompok terjadi tukar menukar ide diantara anggotanya kemudian keberanian siswa mengemukakan pendapat di depan kelas. Penerapan Resource Based Learning dengan memanfaatkan sumber-sumber berupa buku dari perpustakaan membuat pembelajaran lebih bervariasi. Sehingga pembelajaran menjadi tidak monoton bersumber dari pengetahuan dari guru dan modul. Kedua, penerapan model Resource Based Learning dapat meningkatkan kemampuan berpikir historis siswa. Kemapuan berpikir historis merupakan modal yang penting bagi siswa untuk belajar sejarah. Kemampuan berpikir historis dapat membantu siswa memahami peristiwa sejarah dengan baik.

Penelitian ini terbatas pada pemanfaatan sumber-sumber buku sebagai upaya untuk meningkatkan kemampuan berpikir historis. Rekomendasi bagi peneliti lain yang melakukan penelitian sejenis hendaknya menerapkan model Resource Based Learning dengan menggunakan sumber yang berbeda ataupun memilih model pembelajaran yang lain.

\section{Daftar Pustaka}

Aziz, Zahara \& Ismail, N. A. N. I. (2007). Kajian Tinjauan Kesediaan Guru-guru Sejarah Menerapkan Kemahiran Pemikiran Sejarah kepada Para Pelajar. Jurnal Pendidikan 32 (2007), 32, 119-137.

Dasna, I.W. (2008). Penelitian Tindakan Kelas (Classroom Action Research). Pendidikan Dan Latihan Profesi Guru (PLPG) Di PSG Rayon 15. Malang, Indonesia: Universitas Negeri Malang.

Garvey, B; Krug, M. (2015). Model-Model Pembelajaran Sejarah di Sekolah Menengah. Yogyakarta: Ombak.

Hamid, A. (2014). Pembelajaran Sejarah. Yogyakarta: Ombak.

Jati, B.P. (2015). Implementasi Pendidikan Karakter Dalam Pembelajaran Sejarah Pada Kurikulum 2013 di SMA Negeri 1 
Boyolali. Surakarta: Pascasarjana, Universitas Sebelas Maret.

Khaifiyah, A. (2014). Penerapan Metode Inkuiri Dalam Pembelajaran Sejarah Melalui Novel Penakluk Badai Untuk Meningkatkan Kemampuan Berpikir Historis Siswa Kelas XII IPS MAN1 Karanggede. Surakarta: Pascasarjana, Universitas Sebelas Maret.

Kochar, S.K. (2008). Teaching of History. Jakarta: Grasindo.

Murni. (2013). Model Pembelajaran Holistik Pengembangan Ketrampilan Berpikir Kesejarahan: Suatu Penelitian dan Pengembangan Terhadap peningkatan Ketrampilan Berpikir Kesejarahan Mahasiswa Pendidikan Sejarah di Kota Palembang. Bandung: Pascasarjana, Universitas Pendidikan Indonesia.

Ryan, M., Wells, J., Freeman, A., \& Hallam, G. (1996). Resource-based learning strategies: implications for students and institutions. Alt-J, 4(1), 93-98. https://doi.org/10.1080/096877696 0040114

Sagala, S. (2009). Konsep dan Makna Pembelajaran Untuk Membantu Memecahkan Problematika Belajar dan Mengajar. Bandung: Alfabeta.

Santyasa, I.W. (2007). Model-Model Pembelajaran Inovatif. Makalah Disajikan Dalam Pelatihan Tentang Penelitian Tindakan Kelas (PTK) Bagi Guru-Guru SMP Dan SMA, 1-16. Nusa Penida, Indonesia: Jurusan Fisika, Universitas Pendidikan Ganesha.

Sukmadinata, N. S. (2015). Metode Penelitian Pendidikan. Bandung: PT Remaja Rosdakarya.

Sumadayo, S. (2013). Penelitian Tindakan Kelas. Yogyakarta: Graha Ilmu.

Suroso. (2007). Classroom Action Research. Yogyakarta: Pararaton Publishing.

Varshney, B. (2014). Innovative Practices In Teacher Education. Journal of Education and Practice, 5(7), 95-101.

Wijanarti, E. (2012). Model Pembelajaran Kontekstual dalam Pengembangan Pembelajaran Sejarah. Retrieved April 20, 2020, from 2012 website: http://file.upi.edu/direktori/fpips/jur ._pend._sejarah/196207181986012erlina_wijanarti/ctl_dlm_pmblran_sej arah.p

Wineburg, S. (2006). Berpikir Historis: Memetakan Masa Depan, Mengajarkan Masa Lalu (Maris, Mas). Jakarta: Yayasan Obor Indonesia.

Wiriaatmadja, R. (2014). Metode Penelitian Tindakan Kelas. Bandung: PT Remaja Rosdakarya.

Yanzi, H. (2011). Belajar Berbasis Aneka Sumber. Retrieved May 5, 2020, from 2011 website: http://staff.unila.ac.id/hermiyanzi/20 11/08/23belajar-berbasis-anekasumber/ 